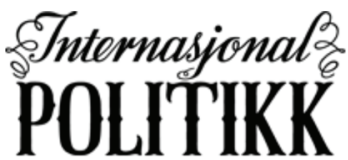 \\ SKANDINAVISK TIDSSKRIFT \\ FOR INTERNASIONALE STUDIER
}

Årgang 78, Nummer 3, side 311-333, 2020, ISSN 1891-1757, www.tidsskriftet-ip.no, Publisert september 2020

\section{Effektive verktøy eller historiske rammer? Kinas holdninger til internasjonale institusjoner}

\author{
Magnus Langset Trøan \\ Norsk Utenrikspolitisk Institutt (NUPI)
}

\begin{abstract}
Sammendrag
I akademia skrives det ofte at stater deltar i institusjoner så lenge dette sammenfaller med deres interesser på ethvert tidspunkt. Implikasjonen av dette er at stater som Kina kanskje vil avvise internasjonale institusjoner så fort de føler at institusjonene ikke er nyttige. Jeg vil hevde at Kina lar sine interesser formes av institusjonene ut over hva ytre rammevilkår vil tilsi. For å belyse dette argumentet tar artikkelen for seg en casestudie med utviklingen av Shanghai-samarbeidsorganisasjonen (SCO) og Kinas holdninger i denne prosessen. Spesifikt vil artikkelen trekke linjer fra forhandlingene mellom Kina og Sovjetunionen over grensespørsmål på 1980-tallet frem til grunnleggingen av SCO på 2000-tallet. Ved å sammenligne en rasjonell tilnærming med en historisk vil artikkelen hevde at den historiske er mer relevant for å forstå Kinas holdninger. Artikkelen argumenterer at en historisk tilnærming har potensial som et nyttig verktøy, og at den bør undersøkes mer innen IR-faget.
\end{abstract}

Nøkkelord: Sentral-Asia • forhandlinger • institusjonalisme • stiavhengighet

\section{Innledning}

De siste tiårene har Kina gjennomgått en voldsom økonomisk, politisk og militær vekst. Folkerepublikken kan allerede nå skryte av å være verdens nest største økonomiske makt, og den ser ut til å kunne vokse til å bli verdens største om noen år. Mange vestlige politikere og akademikere har stilt seg spørsmålet hva dette vil bety

\footnotetext{
^Kontaktinformasjon: Magnus Langset Trøan, e-post: maggern2k@hotmail.com

(C)2020 Magnus Langset Trøan. This is an Open Access article distributed under the terms of the Creative Commons Attribution 4.0 International License (http://creativecommons.org/licenses/by/4.0/), allowing third parties to copy and redistribute the material in any medium or format and to remix, transform, and build upon the material for any purpose, even commercially, provided the original work is properly cited and states its license.

Citation: Trøan, M. L. (2020). Effektive verktøy eller historiske rammer? Kinas holdninger til internasjonale institusjoner. Internasjonal Politikk, 78(3), 311-333. http://dx.doi.org/10.23865/intpol.v78.2142
} 
for den gjeldende verdensordenen som vi her i Vesten har vært så dominerende $\mathrm{i}$ opprettelsen av. Vil vi bli vitne til en parallell verdensorden styrt av Kina, hvor dagens institusjoner som FN, Verdensbanken, Det internasjonale pengefondet og Verdens handelsorganisasjon blir erstattet av nye?

En grunnstein i dagens forskning på staters fremtreden er at de stadig utformer politikk basert på allment relevante interesser som velstand og sikkerhet. Basert på en slik forståelse kan vi argumentere at Kina støtter opp under dagens verdensorden bare midlertidig, fordi den fortsatt tjener deres interesser: Landet nyter rask velstandsøkning og stadig mer politisk innflytelse. Denne artikkelen foreslår en mer nyansert argumentasjon. Den vil hevde at vel så viktig som nyttemaksimering er det at Kina har giort seg erfaringer med dagens orden. Å spille bra påvirker ikke bare tilstanden på spillebrettet, men også spilleren selv. Gode erfaringer og læring er viktige hensyn som tas med i fremtidige vurderinger av hvor nyttig en gitt orden og en strategi er. Dette betyr at stabilitet og gradvise endringer er generelt mer fordelaktige, og at selv med en alvorlig krise er det mindre trolig at Kina vil vende ryggen helt til de institusjonene vi kjenner i dag.

Institusjoner oppstår sjelden fra ingenting og forsvinner sjelden inn $\mathrm{i}$ ingenting. Om vi kaster blikket tilbake på utviklingen av en enkelt institusjon eller en klynge (som Bretton Woods-systemet), vil vi kunne se mer kontinuitet og gradvishet enn argumentasjonen om nyttemaksimering tilsier. Som økonomen Douglass North sier, «utvikler [institusjoner] seg gradvis og knytter sammen fortid, nåtid og fremtid. $[\mathrm{H}]$ istorie er ... en fortelling om institusjonell utvikling» (North, 1991, s. 97). Fordi stater giør seg erfaringer med institusjoner de deltar $i$, vil spesifikke ordninger kunne overleve relativt store skifter i maktforhold, både fordi endring medbringer nye kostnader, og fordi man har nytt godt av gjeldende ordninger.

Dette historiske argumentet for effekten av Kinas vekst må nødvendigvis ha grunnlag både teoretisk og empirisk. I litteraturen på institusjoner har en spesifikk skoleretning nettopp foreslått en slik historisk oppfatning, «historisk institusjonalisme", men den har i liten grad blitt benyttet i studiet av internasjonale relasjoner. Empirisk kan vi for Kinas del se tegn til nettopp en slik gradvis politikkutforming i utviklingen siden Deng Xiaopings reformer på slutten av 1970-årene (Whiting, 2000; Heilmann, 2008), en utvikling uten noe klart endepunkt, men som en kontinuerlig læringsprosess basert på både materielle interesser og immaterielle vurderinger og erfaringer. Selv i utenrikspolitikken ser vi tegn til at Kina gradvis har endret sin oppfatning av internasjonale institusjoner og multilaterale ordninger etter hvert som de har deltatt i dem og gjort seg egne erfaringer (Yuan, 2010, s. 856).

Artikkelen vil søke å samle dette teoretiske og empiriske grunnlaget i en konsis oppfatning av hvordan Kina forholder seg til internasjonale institusjoner over tid. Den vil konkludere med at en historisk modell øker relevansen og den empiriske styrken til analysen. En slik modell kan ikke erstatte en tradisjonell nyttemaksimerende modell, men den er et viktig og verdifullt tilskudd til litteraturen. Teoretisk viser den at historisk institusjonalisme er relevant som tilnærming innenfor faglitteraturen på 
internasjonale relasjoner. Empirisk tilfører analysen et nytt nivå av detaljer, og en ny vinkling som beriker vår forståelse av kinesisk diplomati.

Artikkelens utforming

Artikkelen vil beskrive en historisk modell for en stats holdning til en internasjonal institusjon. Denne modellen vil ta utgangspunkt i en tradisjonell rasjonell modell, men vil inkludere historiske faktorer. Således vil den prøve å bruke det beste av to verdener og skape et utgangspunkt for mer dialog mellom materielle og immaterielle tilnærminger $\mathrm{i}$ faget internasjonale relasjoner.

For å være konsis og nøktern er artikkelen utformet som en casestudie. Den vil se på Kinas rolle og holdninger til utviklingen av Shanghai-samarbeidsorganisasjonen (SCO). Dette er en såkalt avgjørende case hvor de årsakssammenhengene jeg prøver å utheve, burde være tydeligst (Gerring, 2007, s. 89) grunnet Kinas lange historiske og aktive rolle i opprettelsen av organisasjonen, og hvor deres sentrale posisjon og investering av politisk kapital tilsier følsomhet overfor hvordan organisasjonen utvikler seg videre. Dersom modellen skulle vise seg ikke å være særlig relevant i denne casen, vil det være et sterkt argument for å legge den vekk.

Et viktig bidrag for artikkelen vil være å trekke frem kinesiske kilder i større grad enn det som har vært tilfellet tidligere. Kinesisk litteratur presenterer viktige detaljer om Kinas utenrikspolitikk og politiske vurderinger, som i liten grad har blitt fanget opp i vestlig akademia grunnet begrenset fysisk og språkmessig tilgjengelighet. Forfatteren samlet i årene 2016-2018 inn en rekke kinesiske originalbidrag fra de åpne og omfattende bibliotekene tilknyttet Fudan-universitetet i Shanghai, hvorav flere fortsatt er utilgjengelige i digital form. Alle data i artikkelen er kvalitative og er samlet inn via lesing av primær- og sekundærkilder på engelsk og kinesisk, og forfatteren har gjennom samarbeid med kollegaer også samlet inn data fra enkelte russiskspråklige kilder $^{1}$. Dette sørger for en dypere analyse av temaet, da ulike dokumenter velger å fokusere på ulike områder og kanskje unngår andre.

Artikkelen består av fem deler. Den første vil ta for seg hovedtrekk i gjeldende studier av SCO. Den andre vil beskrive det teoretiske grunnlaget og modellen vi vil bruke i analysen. Den tredje vil så analysere fremveksten til SCO med fokus på viktige faktorer. Den fjerde og siste delen vil oppsummere analysen og presentere artikkelens konklusjon.

\section{Shanghai-samarbeidsorganisasjonen i kontekst}

SCO regnes som den første multilaterale sikkerhetsorganisasjonen opprettet av Kina (Chung, 2006, s. 5). Den ble formelt dannet ved undertegnelsen av SCO-erklæringen og Shanghai-konvensjonen om samarbeid for å bekjempe terrorisme 15. juni

\footnotetext{
${ }^{1}$ Jeg ønsker her å takke for god støtte fra mine kollegaer Assel Bitabarova, Yana Hryshko, Galina Kolodzinskaia og Haakon Fossum Sagbakken for bistand til innsamling, oversettelse og stavekontroll.
} 
2001 av Kina og fem naboland: Russland, Kasakhstan, Tadsjikistan, Kirgisistan og Usbekistan. Organisasjonen oppsto likevel ikke i et vakuum. SCO-erklæringen er tydelig på at organisasjonen har sine røtter i tidligere samarbeid, som «Shanghai femgruppen", som igjen er bygget på grense- og nedrustningsforhandlingene mellom Kina og Sovjetunionen fra $1964 .^{2}$ På tross av pågående debatt om organisasjonen vil utvikle seg til en slags EU eller NATO, slår både SCO-erklæringen og Shanghaikonvensjonen fast at organisasjonen først og fremst er dannet rundt ønsket om samarbeid for å bekjempe terror, ekstremisme og separatisme i regionen, heller enn noen union eller formell allianse. ${ }^{3}$ Likevel oppfordrer SCO-erklæringen til sterkere bånd også innen handel og økonomi, forskning, kultur, miljøvern med mer.

Organisasjonen er et populært forskningsobjekt av mange årsaker. Først og fremst er den et interessant ikke-europeisk regionalt forum, noe som kan gi oss bredere forståelse av internasjonale organisasjoner som et fenomen. I tillegg er SCO tett tilknyttet en rekke viktige temaer innenfor internasjonal politikk, som kinesisk og russisk utenrikspolitikk, den internasjonale og regionale ordenen etter Sovjetunionens fall, geopolitisk rivalisering med USA og NATO, og den er et viktig grunnlag for det som etter hvert ble Kinas nye silkevei, «ett belte, én vei».

Det er derfor ikke overraskende at akademia har tilskrevet SCO mange ulike roller. De mest grunnleggende analysene ser vi i for eksempel Sutter (2012, s. 237-237) og Marketos (2009, s. 1-3), som ser SCO som en liten brikke i et større maktspill i Sentral-Asia, hvor Kina og Russland søker å styrke sin egen innflytelse i regionen på bekostning av USA. Nedstengingen av den amerikanske flybasen K2 i Usbekistan i 2005, i etterkant av en felles erklæring fra SCO-statene om at USA burde trekke seg ut av Sentral-Asia, er et tilfelle som støtter en slik argumentasjon (Cooley, 2012, s. 81-83). Forskere som Yuan (2010), Pan (2007), Bailes og Dunay (2007) og Chung (2006) fokuserer mer på samarbeidsaspektet og ser SCO som et kinesisk verktøy for å gjøre det lettere å koordinere med sentralasiatiske land for å undergrave religiøs radikalisering, ekstremisme og fremveksten av transnasjonale terrororganisasjoner som kunne knytte bånd til grupper inne i kinesiske Xinjiang og dermed destabilisere grenseområdet. Song (2013) tegner et mer nyansert bilde, hvor organisasjonen utfyller et virvar av ulike funksjoner, og forklarer det med at organisasjonen er utfallet av en lang rekke forhandlinger mellom flere stater med svært ulike interesser.

Det disse bidragene har til felles, er at de alle ser på organisasjonen som et verktøy for medlemmene, først og fremst Russland og Kina - eller kanskje bare Kina. Chung (2006) går til og med videre og hevder at Kina raskt ville trekke seg ut av organisasjonen dersom den ikke lenger utførte de spesifikke formålene Kina opprettet den for. Dette fokuset på organisasjonen som et rent maktpolitisk spill eller verktøy står i sterk kontrast til en annen del av litteraturen, som ser på den mer som

\footnotetext{
${ }^{2}$ Se f.eks. Lanteigne (2007, s. 606-612) for en enkel oversikt over den historiske utviklingen.

${ }^{3}$ De to dokumentene kan leses i fulltekst her: http://eng.sectsco.org/documents/ (Lesedato: 17.08.2020)
} 
en slags arena for sosialisering blant topplederne. Denne vinklingen ser vi særlig i Zhao (2008, s. 38-39), Ambrosio (2008) og Dadabaev (2013), som alle beskriver organisasjonen som en nøkkel til fremveksten av en regional identitet. Ambrosio og Dadabaev fremhever samtidig organisasjonens rolle i å forsterke de relativt autoritære myndighetene $\mathrm{i}$ regionen gjennom sosialisering og det å finne aksept for sine holdninger gjennom felles vurderinger av demokrati og menneskerettigheter.

Dette skillet i litteraturen legger grunnlaget for en ny tilnærming. En slik tilnærming bør ikke beskrive SCO som et rent verktøy for medlemmene, men heller ikke se bort fra dette og beskrive den som en ren arena for sosialisering. SCO er utfallet av en lang rekke konkrete forhandlinger som strekker seg tilbake over tiår, minst til de kinesisk-sovjetiske forhandlingene i 1964 (Zhang \& Qi, 2014, s. 32), et materielt utgangspunkt som samtidig har skapt viktige erfaringer blant medlemmene. Dette er den brokete oppveksten som Song (2013) henviser til. Faktisk anerkjenner mye av litteraturen denne komplekse historiske bakgrunnen. Selv Sutter (2012, s. 238), med sin i hovedsak maktpolitiske argumentasjon, erkjenner at organisasjonen utviklet seg gradvis over tid, med ulike strategiske hensyn til det geopolitiske landskapet, økonomiske interesser og USAs voksende innflytelse i området etter 2001 som relevante eksterne faktorer som skjøv utviklingen i ulike retninger. Likevel har ingen bidrag i den overnevnte litteraturen brukt denne historiske rammen som en viktig del av analysen. Denne artikkelen vil gjøre nettopp det.

\section{En historisk tilnærming}

Det er en lang tradisjon for å forske på institusjoner innen faget internasjonale relasjoner. Det er likevel svært mange ulike tilnærminger på institusjoners rolle, hvorfor de oppstår, og hvordan de påvirker medlemmenes handlinger. Hovedskillene mellom disse tilnærmingene er fokusert på spørsmålet om en person er et produkt av sitt miljø, eller om vedkommende former sitt eget miljø. Siden den såkalte behavioristiske revolusjonen i faget i etterkrigstiden har pendelen i hovedsak svinget mot det førstnevnte, hvor man koker handlingsmønstre ned til klare årsakssammenhenger «hvis a, så b». En slik deterministisk oppfatning fører til at man forklarer for eksempel fremveksten av NATO med den dynamikken som oppstår når to maktblokker står mot hverandre, og som derfor er et sannsynlig utfall dersom de samme vilkårene skulle oppstå igjen senere. En rasjonell modell forklarer dette med at aktører styres av klare nyttevurderinger basert på objektive verdier, som økonomiske, militære eller politiske interesser for stater (Keohane, 1984, 1988; Axelrod, 1984). I essensen betyr dette at institusjoner har en målbar verdi for medlemmene og er prisgitt denne. Fordi modellen antar at ytre rammevilkår dikterer aktørenes handlemåte og institusjonenes utforming, er den ikke like relevant når man ønsker å se på endringer $\mathrm{i}$ institusjoner over tid. Den fungerer best når man tar et stillbilde og «leser av» rammevilkårene fra hvordan institusjonen ser ut (Thelen, 2004, s. 214-216). Denne forståelsen av institusjoner som verktøy med varierende grad av viktighet ligger til 
grunn i en betydelig del av faglitteraturen, og det meste av litteraturen på SCO nevnt tidligere, gjør nettopp også det.

Ikke overraskende møter slike modeller mye kritikk nettopp fordi de er sterkt forenklet i bytte mot analytisk eleganse. Kanskje det viktigste motargumentet er at ikke alle aktører er skapt like, og a leder ikke alltid til b. Dette kommer av at aktører som mennesker og stater er sosiale enheter som samhandler, lærer og erfarer i kontekst av rammevilkårene (Hall \& Taylor, 1996, s. 954). Institusjoner oppfattes her som immaterielle sosiale byggverk, som endres i takt med hvordan medlemmene forholder seg til dem. For eksempel hvordan NATO har blitt arena for å fostre samhold og støtte opp om felles verdier som demokrati og menneskerettigheter.

Den historiske tilnærmingen på institusjoner søker å fylle rommet mellom denne materielle og immaterielle oppfatningen. Først og fremst søker såkalt historisk institusjonalisme å trekke en tråd mellom stillbildene som brukes i rasjonelle modeller for å beskrive en utviklingstrend. For å gjøre dette på en helhetlig måte brukes både materielle og immaterielle faktorer for å forklare hvordan eksisterende institusjoner spiller en rolle i dannelsen av nye. Denne retningen beskriver dermed institusjonen og samhandling mellom medlemmene som et nivå av faktorer mellom ytre rammevilkår og medlemmene selv. Når det skjer avgjørende endringer i ytre rammevilkår, ytre sjokk, setter dette dermed i gang en prosess hvor disse endringene ikke leder til automatiske endringer i institusjonen, men «oversettes» gjennom medlemmenes investerte materielle og immaterielle verdier (Hogan, 2006). Dette betyr at bestemmelser gjort på et tidspunkt, kan ha stor effekt, selv lenge etterpå, og at rasjonelle stillbilder derfor ikke gir noe godt bilde dersom man ønsker å se på institusjonens utvikling. Pierson (2003) sammenligner denne forståelsen med offentlige prosjekter, hvor det ofte vil ta år før man får et godt bilde av hvilken effekt prosjektet vil ha på samfunnet

La oss forklare dette med et eksempel: NATO er en tradisjonell militærallianse som opprettes for å samle militære styrker i møte med Sovjetunionen og østblokken. Gjennom flere tiår bygges det opp en omfattende militær struktur hvor alle medlemmenes sikkerhet knyttes opp til NATO, og man deler etterretning, utstyr og kommandokjeder. Samtidig skaper denne stabiliteten samhold og tillit mellom medlemmene, man får en oppfatning av at hvert medlems sikkerhet er avhengig av alles sikkerhet, og man får en felles forståelse av de trusler som alliansen står overfor, selv om hvert medlems materielle situasjon er unik. Når østblokken faller og NATOs tradisjonelle trussel forsvinner, kan man argumentere at det ikke lenger er noe grunnlag for medlemmene å beholde alliansen. ${ }^{4}$ Likevel har medlemmene investert så mye i alliansen både materielt og immaterielt over tid, at de tilpasser NATO nye roller heller enn å skape nye institusjoner.

\footnotetext{
${ }^{4}$ Dog vil forskere med fokus på maktpolitiske faktorer kunne argumentere at USAs hegemoniske stilling i Europa er den egentlige bærebjelken i alliansen, og at denne fortsatt består.
} 
Modell for analysen

Historiske modeller har faktisk blitt brukt svært lite på internasjonale institusjoner. En av hovedutfordringene har vært at historisk institusjonalisme har vært dominert av historikere, som har hatt mer fokus på beskrivelse enn analyse av årsakssammenhenger og generelle prinsipper. Det har likevel vært enkelte bidrag som har søkt å utbedre dette problemet. Her har særlig Thelen (2004), Thelen og Steinmo (1992) og Fioretos (2011) vært innovative, og Fioretos har til og med gjort tidlige forsøk på å bruke historisk institusjonalisme på internasjonale institusjoner. Det er basert på disse forskernes bidrag at jeg utformer modellen i denne artikkelen, dog med en del egne innovasjoner for ytterligere pålitelighet og relevans.

La oss først beskrive hvordan universet ser ut (ontologisk modell). Vi tenker oss en gitt institusjon og medlemmene som et internt miljø, og utenfor dette er det ytre rammevilkår (verden for øvrig). Institusjonen regner vi her som «formelle og uformelle prosedyrer, rutiner, normer og konvensjoner som er bygget inn i en organisasjonsstruktur» (Hall \& Taylor, 1996, s. 938). ${ }^{5}$ Når medlemmene går sammen i institusjonen, skjer dette på grunnlag av de ytre rammevilkårene, og når disse endres, vil vi anta en slags endring i institusjonen også. Vi kan likevel ikke anta at endringer i institusjonen nødvendigvis vil skape endring i verden for øvrig, grunnet forskjell i størrelse. Forfatteren vil i denne artikkelen gå ett skritt videre. Fordi fokuset er på ett medlem, Kina, og landets holdninger til institusjonen og forhandlingene, vil jeg utvide "ytre rammevilkår» til også å gjelde innenrikspolitiske hensyn for Kina. En av de mest populære modellene for hvordan innenrikspolitiske hensyn påvirker statsledere i forhandlinger, er Putnams «tonivåspill» (1988; se også Evans, Jacobson \& Putnam, 1993). Vi trenger ikke å gå i detalj, men tanken i modellen er at mulige forhandlingsløsninger i hovedsak bestemmes av hvor ønskene til innenriksaktører, statslederne og de andre forhandlingspartene overlapper. I denne artikkelen vil vi gå ut fra at innenriksaktører i Kina i hovedsak har svært begrenset direkte innflytelse på forhandlingene, men at de har en indirekte innflytelse via at ledelsens hensyn til innenrikspolitiske problemstillinger til en viss grad styrer hvilke løsninger de anser som mulige og ønskelige. ${ }^{6}$

Thelen og Fioretos har beskrevet en rekke årsaksmekanismer som forklarer hvordan institusjoner forblir stabile eller endrer seg. Forfatteren har kategorisert disse under to hovedfaktorer, preferanser og maktforhold, og vil her fremheve de som anses som mest relevante for analysen. Ytre rammevilkår og institusjonen former statsledernes preferanser, som bestemmer hvordan de ønsker at institusjonen skal se ut. Ytre rammevilkår, som militære, økonomiske og politiske ressurser (som ikke bestemmes av institusjonen), bestemmer samtidig maktforholdene, altså i hvilken grad de er i stand til å dominere forhandlingene. Thelen (2004, s. 231-233) foreslår at vi deretter deler mekanismene inn i de som stabiliserer og endrer institusjonen.

\footnotetext{
${ }^{5}$ I denne artikkelen brukes både «institusjon» og «organisasjon» om hverandre.

${ }^{6}$ Denne oppfatningen baseres på et interessant bidrag om Kinas styringsmodell av Song (2016).
} 
Som vi har sett, legger historisk institusjonalisme vekt på at institusjonen stabiliserer, og at dens innflytelse styrker seg over tid. Dette foregår langs to dimensjoner:

1. Materielt blir institusjonen sterkere ved at stadig nye avtaler, organer og regelverk blir dannet med utgangspunkt i eksisterende rammeverk. Dette betyr at det blir gradvis mindre kostbart å tilpasse seg rammeverket og mer kostbart å begynne på nytt. Samtidig vil stadig flere aktører ta hensyn til rammeverket $\mathrm{i}$ sine handlinger, og nye aktører vokser frem inne i rammeverket, noe som gjør samarbeid enklere og tillit større, fordi man føler at det er enklere å forutsi hva som er $\mathrm{i}$ andres interesse.

2. Immaterielt sosialiserer medlemmene med hverandre, og de får gjennom innrømmelser og prinsipper forsterket oppfatninger av hva som er rettmessig deres. Dette er en påvirkning som kan bli avgjørende på tidspunkt hvor materielle interesser kanskje ikke er så fremtredende.

Når det gjelder endring, er vårt hovedfokus viktige endringer i ytre rammevilkår. Dette trenger ikke å være «sjokk», men kan også skje gradvis. Som sagt er artikkelens fokus ikke å beskrive hva slags endringer som fører til en endret institusjon, men heller hvordan slike endringer oversettes i institusjonen. Likevel vil det være nyttig å tenke seg hvor vi mest sannsynlig kommer til å se avgiørende endringer. Forfatteren vil her følge Piersons råd (2000, s. 265-266) og fokusere på de faktorene som har vært ledende for å utforme institusjonen i begynnelsen, da det er endringer nettopp her som mest sannsynlig vil skape endringer i institusjonen (mer om dette under).

Maktforholdet vil i denne artikkelen spille en mindre rolle. Forfatteren vil støtte seg til Waltz' (1979) definisjon av makt som en sum av militære, politiske og økonomiske ressurser som utgjør staters sikkerhetsfølelse. I artikkelen vil dette i utgangspunktet giøre seg gieldende i form av tradisjonelle sikkerhetstrusler og geopolitikk. Den vil ikke analysere maktbegrepet nærmere.

Hypotesen vi ønsker å teste, er dermed at ved skiftende rammevilkår vil institusjonelle hensyn føre til at man kanaliserer nye preferanser og maktforhold inn i eksisterende institusjoner heller enn å starte på nytt. Samtidig vil man begrense endringer grunnet hensyn til de investeringer man allerede har gjort. Sammen fører dette til en tendens til å holde seg stort sett i samme spor (kalt «stiavhengighet»). Altså vil den historiske bakgrunnen (materielt og immaterielt) gjøre seg gjeldende som en årsak i de observasjoner vi gjør, selv om endringer i rammevilkår er utløsende for endringer i preferanser og maktforhold.

\section{Analysens utforming}

Fokuset for artikkelen er utviklingen av SCO, fra de kinesisk-sovjetiske grenseforhandlingene og frem til dagens organisasjon. Det å gjennomføre analyser av enkelte avgjørende caser blir mye kritisert innenfor samfunnsvitenskapen grunnet faren for metodefeil når man bare har én observasjon (se bl.a. King, Keohane \& Verba, 
1994, s. 208-230; Collier, Mahoney \& Seawright, 2004). Selv om denne artikkelen av plasshensyn ikke kan ta for seg mange caser, kan vi velge et kompromiss og dele SCOs utvikling inn i flere caser. ${ }^{7}$ Vi kan dermed analysere hypotesens relevans innenfor hver «runde» med endringer i ytre rammevilkår og observasjoner på Kinas handlinger og vurderinger mot SCO. Artikkelen vil her begynne med den siste forhandlingsrunden mellom Sovjet og Kina, som begynte i 1986. Dette er et godt utgangspunkt, da det er her vi ser selve kimen til forhandlingene etter den kalde krigen. La oss deretter dele inn den påfølgende perioden i like femårsblokker, som ikke bare overlapper med endringer i lederskapet i Kina, men også med viktige endringer i forhandlingsinstitusionen. Forfatteren setter sluttpunktet til 2006, da SCO på dette punktet allerede er en godt utviklet organisasjon. Dette gir oss fire caser: case I (1986-1991), case II (1991-1996), case III (1996-2001) og case IV (2001-2006).

I hvert tilfelle vil jeg dele data klart inn i ytre rammevilkår og observasjoner på Kinas handlinger og vurderinger. Førstnevnte vil da i hvert tilfelle være den realiteten som møter Kina, og sistnevnte vil være hvordan Kina handler, basert på disse og institusjonen. Hypotesens styrke vil da måles på bakgrunn av hvor mye institusjonelle hensyn trer frem når Kina møter nye rammevilkår. De ulike casene vil samtidig kunne utheve ganske ulike endringer i ytre rammevilkår, da Kinas stilling og interesser i 1986 så ganske annerledes ut sammenlignet med i 2006. Det gir oss derfor et relativt godt utgangspunkt for å se hvordan Kinas vurderinger på institusjoner eventuelt endrer seg når ting som maktforhold og interesser endrer seg.

Vi må til slutt klarlegge hvordan vi ønsker å måle hypotesens styrke, og dermed vise hvor relevant denne historiske modellen er for SCOs utvikling. Fordi vi har gått vekk fra de universelle slutningene som rasjonelle modeller bruker, kan vi ikke uten videre tallfeste eller enkelt måle data mot gitte indikatorer. Det vi observerer, er prosessen hvor Kina oversetter rammevilkår i nye vurderinger, noe som er spesifikt for Kina og den rammen vi har satt (Brady, Collier \& Seawright, 2006). Bennett (2010) foreslår at vi går frem som en detektiv, med ulike hypoteser i hodet og som velger den hypotesen som best passer de dataene vi har tilgjengelig. I hver case vil jeg derfor belyse hvordan en tradisjonell rasjonell modell ville ha sett på dataene, og vise hvordan vår historiske modell presterer i forhold. Fordi vi bruker en populær og universell hypotese samt en som tar hensyn til materielle vurderinger, vil det være stor overlapp mellom modellene.

Det viktigste blir å finne data som er nødvendig for at den historiske modellen kan være relevant, altså nok til at vi kan bekrefte at modellen er relevant. Det vi likevel ønsker oss, er en rykende pistol, ${ }^{8}$ en observasjon som ikke er nødvendig for å hevde

\footnotetext{
${ }^{7}$ Dette er løsningen som blant annet foreslås av nettopp King, Keohane og Verba (1994, s. 208-230).

${ }^{8}$ Dette er en av de fire testene som Bennett (2010, s. 210-211) beskriver.
} 
at pistolen har blitt avfyrt, men som er tilstrekkelig for at dette er mer sannsynlig enn andre forklaringer. Altså må vi finne observasjoner som er tydelige tegn på at en historisk tilnærming er mer relevant enn en ren rasjonell en. Dette vil medføre at vi ikke bare kan trekke linjen direkte til ytre rammevilkår, men at det på viktige punkter må kunne vises til at historiske hensyn motarbeidet eller avledet effekten fra disse rammevilkårene. For å måle dette må vi undersøke dokumenter og uttalelser samt analysere utformingen av institusjonen. En rykende pistol vil for eksempel være når Kina ser bort fra mulige gevinster fra ytre rammevilkår for å unngå kostnader med å reforhandle institusjonen.

\section{Casestudie: Shanghai-samarbeidsorganisasjonen}

Den historiske rammen

Som nevnt over vil den enkelte case bestemme hvilke konkrete faktorer vi bør følge med på. Vi har utpekt «ytre rammevilkår» samt «materielle hensyn» og «immaterielle hensyn" som de avgjørende dimensjoner. Når det gjelder ytre rammevilkår, tar vi utgangspunkt i de interessene som var styrende for Kina da de begynte forhandlingene med Sovjet i 1986, da det er endringer i disse interessene som er ledende for endringer i Kinas vurderinger. Forhandlingene handlet i forste rekke om å bli enige om grensen $\mathrm{i}$ tillegg til tillitsbyggende tiltak og nedrustning i grenseområdet. Li Fenglin (2011, s. 10) gjør det i tillegg klart at hovedmotivasjonen for Kina var å stabilisere grensen og forholdet til Sovjetunionen slik at man kunne legge til rette for handel og økonomisk vekst. Det blir derfor naturlig at vi fokuserer på sikkerhet og økonomiske interesser som ytre rammevilkår i den videre analysen.

Ved begynnelsen av vår første case kommer Kina inn i forhandlingene med lang erfaring med Sovjetunionen, og med en historisk bagasje som underbygget grensetvistene. Dette omfatter både materielle og immaterielle hensyn.

\section{Materielle hensyn}

Grensetvistene mellom Kina og Sovjetunionen hadde en kompleks bakgrunn. Store områder hadde blitt avstått til Tsar-Russland på grunnlag av de «ulikeverdige traktatene» som Kina ikke lenger anerkjente. Samtidig hadde Tsar-Russland i fjellområdet Pamir i vest også okkupert områder langt inn på det som hadde blitt satt av som kinesisk territorium i disse traktatene, og på flere områder gikk ikke kinesiske og russiske kart overens. Mange ulike spørsmål måtte derfor tas hensyn til i eventuelle grenseforhandlinger ( $\mathrm{Li}, 2011$, s. 3-6).

Under forhandlingsrundene i 1960-årene hadde Kina og Sovjetunionen gått langt i å konkretisere de ulike kravene. De hadde samlet sammen kartgrunnlag og historiske dokumenter, samtidig som de ulike partene kunne nedfelle sine standpunkter og motsvar i møtereferater (Fravel, 2008, s. 120-121). For å håndtere dette materialet hadde Kina opprettet et eget byråkrati innenfor kinesisk UD med særskilt ekspertise på grensetvistene (Di, 2015). 
Immaterielle hensyn

For Kinas del hadde grensetvistene med Sovjet viktige elementer av immateriell verdi grunnet tilknytningen til de ulikeverdige traktatene. De sto som monumenter for det såkalte "ydmykelsens århundre», hvor kolonimaktene, deriblant Tsar-Russland, hadde overtatt betydelige områder langs grensene fra det kinesiske keiserdømmet på 1800-tallet. For Kina var det derfor avgjørende at man gjennom forhandlinger fikk anerkjennelse for at traktatene hvor de hadde avstått disse områdene til Tsaren, var ulikeverdige og urettmessige (Deng, 1993, s. 293). Kina omtalte grensetvistene som "problemer nedlatt av historien» heller enn forhandlinger over materielle verdier. På samme måte fastholdt Deng Xiaoping at de skulle løses med «hensyn til dagens realiteter», såfremt Sovjetunionen anerkjente nettopp dette poenget (Deng, 1993).

Case I: 1986-1991 - solnedgang over Sovjet

Ytre rammevilkår

Perioden frem mot Sovjetunionens fall i 1991 kjennetegnes av en rask oppvarming av forholdene mot både Vesten og Kina. I Beijing har Deng Xiaoping beskrevet «tre hindre» til normalisering av forholdet, basert på Kinas vurderinger av den strategiske sikkerhetstrusselen som Sovjet og dets allierte utgjorde. Disse omfatter sovjetiske hærgrupper langs den kinesiske grensen mot Mongolia, Sovjets invasjon av Afghanistan og sovjetisk støtte til Vietnams okkupasjon av Kambodsja (Harding, 1988, s. 20-22). Da Sovjet i 1986 og 1987 begynner tilbaketrekking fra Afghanistan og Mongolia, går Kina omsider med på å starte politiske konsultasjoner (Tian, 1993, s. 329-330).

For begge sider er sikkerhetsspørsmål på toppen av agendaen, spesifikt en endelig løsning på grensetvistene. Samtidig har Dengs reformpolitikk i Kina satt økonomisk utvikling i sentrum av kinesisk politikk, og statsminister Li Peng ivrer allerede i 1986 for økt handel med Sovjetunionen for å styrke økonomisk utvikling i Xinjiang (Zhu \& Duan, 2002, s. 233). Dette hensynet blir desto viktigere da vestlige land innfører politisk, militær og økonomisk boikott av Kina etter hendelsene på Tiananmen sommeren 1989. Handel med Sovjet blir nå sett på som et viktig steg i å normalisere forholdet til stormaktene og skape et bedre klima for økonomisk vekst i Kina ( $\mathrm{Li}$, 2010, s. 10).

\section{Observasjoner på kinesisk atferd}

Når Kina og Sovjetunionen gjenopptar formelle forhandlinger i februar 1987, er det en klar endring i stemning fra tidligere runder (Yao, 2015). Skiftet er delvis drevet av ønsket om økt handel, og økonomiske forhandlinger går parallelt med de over grensespørsmålet (Li, 2010, s. 10; Savkovitsj, 2010, s. 87). Med utgangspunkt i eksisterende materiale og enighet blir det rask fremgang på flere områder, og partene blir allerede første dag enige om prinsippene for en endelig løsning (Ide, 2014, s. 103). Langs grensen i øst fastholder Kina sitt krav fra tidligere runder, og med sovjetisk ettergivelse her kan de signere en første traktat i mai 1991 (Vereshchagin, 
1999, s. 239-240). Samtidig har Sovjetunionens tilbaketrekking fra Mongolia og Afghanistan banet vei for nedrustning i grenseområdet og tillitsbyggende tiltak. Med utgangspunkt i tidligere konsultasjoner slår partene fast at eksisterende grense skal gjelde frem til en endelig løsning, og under Gorbatsjovs statsbesøk i 1989 begynner forhandlingene for fullt på det militære området (Vereshchagin, 1999, s. 235-236).

Å sikre denne prosessen står sentralt for den kinesiske delegasjonen. Et tydelig tegn på dette kommer i 1991, når den sovjetiske delegasjonen ønsker å invitere representanter fra sovjetrepublikkene Kasakhstan, Kirgisistan og Tadsjikistan til forhandlingsbordet. På denne tiden har voksende autonomi blant republikkene begynt å forskyve Moskvas kontroll i grenseområdene, noe som giør det viktigere å sikre lokale myndigheters involvering i forhandlingene (Ro'i, 1992). Kina er dog motvillig overfor å godta disse delegatene, da man er bekymret for at de nye partene ikke vil godta eksisterende avtaler. Bare når Sovjets delegasjonsleder forsikrer kineserne om at alle avtaler og prinsipper ville bli overholdt av de nye delegatene, går Kina med på deres deltakelse (Amanzholova, Atanov \& Turarbekov, 2006, s. 45).

\section{Oppsummering}

Utgangspunktet for forhandlingene på slutten av 1980-tallet er en ny sikkerhetspolitisk og økonomisk virkelighet. Kina vektlegger økonomisk vekst samtidig som Sovjetunionen trekker seg tilbake fra Mongolia og Afghanistan. Å starte forhandlinger med Sovjetunionen og legge grenseproblematikken bak seg ser derfor ut til å være $\mathrm{i}$ Kinas interesse, noe som kan forklare hvorfor slike forhandlinger blir igangsatt.

Når det gjelder den historiske rammen, ser vi at partene tar utgangspunkt $\mathrm{i}$ eksisterende avtaler. Dette gir mening både materielt og immaterielt. På den ene siden har de allerede i 1960-årene lagt grunnlaget for hvordan kravene ser ut, hva som er utgangspunktet for grensetvistene, og den historiske bakgrunnen i ulikeverdige traktater. Når de bekrefter og bygger videre på denne enigheten, er veien mye kortere til en endelig enighet. Dette må sies å være nødvendige bevis for hypotesen. En historisk tilnærming er relevant i denne sammenhengen.

Det kan på den andre siden ikke hevdes at disse dataene er tilstrekkelige for å velge en historisk tilnærming heller enn en rasjonell. Det nevnes at det er et klart stemningsskifte i denne runden i forhold til tidligere, hovedsakelig grunnet de økonomiske og sikkerhetspolitiske interessene. Det kan derfor argumenteres at partene kan ha kommet til enighet og ha jobbet seg videre, selv uten den historiske rammen. Kinas holdning til utvidelse av den sovjetiske delegasjonen er derimot avgiørende. Selv om det å involvere lokale myndigheter i seg selv kan ses på som svært relevant i handelsøyemed, avviser Kina en slik utvidelse utelukkende på grunnlag av eksisterende avtaler. De går til slutt med på utvidelsen dersom de nye delegatene tilpasser seg avtaleverket, noe som ikke bare skal vise seg å være et viktig valg for videre utvikling i institusjonen, men også et valg som er tilstrekkelig for å vise at den historiske rammen var avgiørende for Kinas holdning. 
Case II: 1991-1996 - nye grenser

Ytre rammevilkår

Sovjetunionens fall har store ringvirkninger på Kinas interesser innenfor både sikkerhet og økonomi. Først og fremst betyr det et stort maktskifte, hvor Kina gikk fra å møte en supermakt til en gruppe unge og ustabile stater i Sentral-Asia (Fravel, 2008, s. 126). Russland består som militær stormakt og beholder kontrollen over flere store militære avdelinger utstasjonert i regionen, men utgjør ikke lenger noen invasjonstrussel mot Kina (Fravel, 2008).

Samtidig mister Moskva kontrollen over folkegruppene i regionen, som strekker seg på tvers av landegrensene, også inn i Xinjiang. Kinas umiddelbare sikkerhetspolitiske hensyn skifter derfor raskt fra tradisjonelle militære trusler til stabilitet i grenseområdet, og til det å unngå at radikale islamske grupper beveger seg over grensen og destabiliserer Xinjiang (Plater-Zyberk \& Monaghan, 2014, s. 2; Fravel, 2008, s. 156). I 1992 ser vi nettopp en slik effekt, når kaoset i Sentral-Asia og spenninger i Xinjiang leder til en voldsbølge, med flere bombeangrep gjennom året. I respons legger Kina store begrensinger på trafikk og handel, i påvente av at nabolandene skal stabilisere seg (Sheives, 2006, s. 208).

Imidlertid ser kinesiske ledere store muligheter for økonomisk samkvem med de unge sentralasiatiske republikkene. Økonomisk vekst og handelssamarbeid blir sett på som sentralt for å stabilisere grenseområdet og sikre grensen (Tian, 1993, s. 629). I juni 1992 ser statsrådet det som forsvarlig å fortsette åpningen av Xinjiang og godkjenner lokale myndigheters anmodning om å gjenåpne grensene og styrke handelsforbindelsene (Zhu \& Duan, 2002, s. 234-235). I møter med delegater fra de nye republikkene uthever utenriksminister Qian Qichen hvor viktig det er for Kina å utvikle gode naboforhold og sørge for regional stabilitet, samt hvor kritisk det er å legge til rette for videre økonomisk vekst i grenseområdene (Liu, Sun \& Liu, 1996, s. 200; Tian, 1993, s. 326). Særlig gjelder dette muligheten for å utvikle Sentral-Asia som gjennomfartsåre mot Europa og gjenopplive Silkeveien (Tian, 1993, s. 326).

\section{Observasjoner av atferd}

Raskt etter at de sentralasiatiske republikkene blir uavhengige, sender Kina en delegasjon for å etablere mellomstatlige forhold. For Kinas del er det avgjørende at de unge republikkene anerkjenner grensetvistene og Kinas historiske krav, og dette blir lagt til grunn i felles erklæringer (Liu, Sun \& Liu, 1996, s. 180). Russland godtar dette som Sovjetunionens formelle arvtaker, og forhandlingene kan her fortsette som en direkte fortsettelse fra 1991 (Liu, 2005, s. 349). Dette gjelder også forhandlingene om nedrustning og tillitsbyggende tiltak, da Russland beholder kontrollen over betydelige militære styrker og grensevakter i området, inkludert den 201. infanteridivisjon i Tadsjikistan (Paramonov \& Stolpovskiy, 2009).

Overfor de sentralasiatiske republikkene er bildet annerledes, og kinesiske forhandlere er bekymret for hva som skal skje med det eksisterende avtaleverket her (Yao, 2015). Det tar gjentatte forsøk fra Kina før republikkene går med på å 
anerkjenne at deres grenser fra første stund er under strid og er den historiske bakgrunnen til tvistene (Liu, 2011, s. 212). Til slutt lykkes Kina, og de enigheter de oppnådde med Sovjetunionen, blir grunnlaget for videre forhandlinger (Liu, Sun \& Liu, 1996, s. 201). Kina ønsker i utgangspunktet å fortsette forhandlingene i et bilateralt format, men det blir raskt klart at dette vil bli teknisk vanskelig, da alt historisk materiale ligger nedlåst i de russiske arkivene i Moskva (Amanzholova, Atanov \& Turarbekov, 2006, s. 47). For å løse dette ber Kina Russland om assistanse (Liu, 2005, s. 363), og Russland tar initiativ til å danne en felles delegasjon for å møte Kina, noe kinesiske forhandlere uttrykker «lettelse» over (Yao, 2015). Denne felles delegasjonen, med Russland i ledelsen, fortsetter så forhandlingene. Kinas delegasjonsleder uttrykker at det er som om Sovjetunionen aldri forsvant [sic] (Yao, 2015).

Med basis i eksisterende avtaler fortsetter forhandlingene raskt. Russland ratifiserer grenseavtalen som Sovjetunionen signerte i 1991, og Kina og Russland undertegner en intensjonsavtale for nedrustning og tillitsbyggende tiltak allerede i 1992 (Liu, 2005, s. 350). Etter toppmøter i 1994 og 1995 kan den forente delegasjonen og Kina tegne opp endelige utkast til avtalene (Liu, 2005, s. 350). Også mot de sentralasiatiske republikkene går forhandlingene raskt fremover. Partene blir enige om først å utforme avtaler der Kina og Sovjetunionen hadde vært enige, og de første avtalene med Russland og Kasakhstan står klare i 1993 (Liu, 2005, s. 364).

\section{Oppsummering}

Kina har både økonomiske og sikkerhetspolitiske interesser i forhandlingene med de unge republikkene. På den ene siden ser man store muligheter for handel, og på den andre siden ønsker man å stabilisere grensen. Det store maktskiftet gir Kina samtidig rom for å kunne presse på kravene sine.

Likevel ser vi tydelige valg som er tilstrekkelige for å bruke en historisk tilnærming. Først og fremst ser vi dette i Kinas forsøk på å få de nye republikkene til å anerkjenne det forhandlingsgrunnlaget som står igjen etter Sovjetunionen. Dette er ikke hensyn som bare er tekniske, men også strategiske. Kina gjør ingen klare forsøk på å øke eller presse frem sine krav, men krever bare at motpartene anerkjenner de standpunktene som har blitt fremmet tidligere. Samtidig oppmuntrer Kina til en forhandlingsform hvor de møter fire stater samlet mot seg, utelukkende fordi de ønsker at forhandlingene skal kunne fortsette i samme spor.

Selv om Kina etter ytre rammevilkår har interesse av å legge grensetvistene bak seg, er det derfor klare henvisninger til den historiske rammen. Disse valgene er ikke utvetydig historiske, men er tilstrekkelige for å hevde at historiske hensyn var svært viktige for Kinas holdning til forhandlingsinstitusjonen.

Case III: 1996-2001 - et gryende samarbeid

Nye rammevilkår

Perioden 1996-2001 representerer ikke noen omveltende endringer på samme måte som den kalde krigens slutt. Likevel ser vi et avgjørende skifte i Kinas agenda mot 
regionen. Viktige faktorer som begynte å gjøre seg gjeldende i årene etter Sovjetunionens fall, ble stadig mer fremtredende.

Først og fremst gjelder dette sikkerhetsdimensjonen. 1996 og 1997 ble et veiskille for kinesiske ledere, da voksende uro i provinsen gjennom 1990-årene resulterer i omfattende demonstrasjoner og voldsepisoder. Etter en inspeksjonstur samler Jiang Zemin regjeringen, og man bestemmer at ledere på alle nivåer må mobiliseres i felles bekjempelse av de såkalte tre ondskaper - ekstremisme, terrorisme og separatisme - og sikre stabilitet og territoriell integritet i området (Zhu \& Duan, 2002, s. 254-259). Samtidig foregår det et skifte der kinesiske ledere i økende grad legger fokus på den regionale dimensjonen, og man identifiserer pantyrkiske og fundamentalistiske bevegelser i regionen som sentrale for å løse krisen i Xinjiang (Pan, 2007; Fravel, 2008, s. 155). Særlig bekymringsfull er Talibans maktkonsolidering i Afghanistan i 1998 (Chung, 2004, s. 991). Denne legger grunnlaget for å søke økt samarbeid med nabostatene i å bekjempe disse truslene. (Fravel, 2008, s. 156).

Samtidig begynner man å se stadig økende økonomiske interesser i regionen. Handelen mellom Kina og Sentral-Asia vokser raskt etter 1998 (Zhao, 2008, s. 45). Samtidig blir økonomiske hensyn knyttet opp til regional sikkerhet, da man ser økonomisk utvikling sentralt i å skape stabilitet og undergrave de tre ondskaper (Zhu \& Duan, 2002, s. 2, 245). I sin vurdering fra 1996 legger Kinas lederskap vekt på regionens enorme naturressurser som utgangspunkt for denne utviklingen, med henvisning til funn og utvikling av tre enorme oljefelt i 1989 og tidlig i 1990-årene i tillegg til Xinjiangs potensielle posisjon som knutepunkt for handel og økonomi i hele regionen (Zhu \& Duan, 2002, s. 237-239).

\section{Observasjoner av atferd}

I forhandlingsinstitusjonen fortsetter arbeidet med grunnlag i tidligere avtaler. I 1996 og 1997 kan de fem partene i forhandlingene (Kina på én side og de andre fire på den andre siden) signere avtaler om nedrustning og tillitsbyggende tiltak i grenseområdet. Dette blir de første multilaterale toppmøtene mellom partene. Mellom 1996 og 1998 blir samtidig en rekke grenseavtaler underskrevet, og med dette begynner tradisjonelle hensyn til sikkerhet og grenser for første gang etter den kalde krigen å flyttes ned på agendaen til fordel for andre spørsmål (Zhao, 2008, s. 60). Erfaringer fra flere år med positive forhandlinger og nye avtaler for tillitsbyggende tiltak fører til at det nå er tilstrekkelig tillit mellom partene til å se på begrenset samarbeid mot felles sikkerhetstrusler (Zhao, 2008, s. 57-60).

Selv om det bestrides hvem som tar initiativ til ytterligere møter, er det klart at alle partene ser det som nyttig å fortsette de multilaterale toppmøtene. De møtes på nytt i 1998, og det første møtet i 1996 blir kjent som startskuddet for «Shanghai fem-gruppen» (Wang, 2001, s. 76). I hvert påfølgende år holdes nye toppmøter, og den felles delegasjonen mot Kina viker plass for et mer likeverdig, multilateralt format (Xu, 2001, s. 2). På toppmøtene mot år 2000 signeres felles erklæringer som oppsummerer og bekrefter eksisterende avtaleverk, samtidig som partene øker fokus 
på felles sikkerhetstrusler. I 1999 blir de enige om å opprette et kontraterrorsenter i Bisjkek, som skal koordinere sikkerhetstjenestene i de fem landene i operasjoner på tvers av grensene (Chung, 2004, s. 991; Trofimov, 2002).

I år 2000 holder «Shanghai fem-gruppen» sitt siste møte. Russland foreslår at gruppen skal utvides til å omfatte Usbekistan, men dette stiller Kina seg negativt til. Usbekistan ikke er part i avtalene som legger grunnlaget for gruppen, og Kina har ikke noe ønske om å reforhandle disse (Trofimov, 2002). Usbekistan ender med å delta som observatør, separat fra de opprinnelige medlemmene. Samtidig oppsummerer partene den fremgangen de har hatt, og de danner en koordineringsgruppe for å utvikle samarbeidet til å dekke nye dimensjoner (Xu, 2001, s. 2).

\section{Oppsummering}

Forhandlingsinstitusjonen ut over i 1990-årene viser klare tegn til en gradvis utvikling. Etter hvert som partene kommer til enighet på gamle områder, flyttes fokuset gradvis over på nye problemstillinger. Fra opprettelsen av «Shanghai fem-gruppen» begynner partene en serie toppmøter hvor de stadig henviser til eksisterende avtaleverk som et viktig utgangspunkt for videre utvikling. Dette, samt det faktum at de nye problemstillingene blir tatt opp i gruppen heller enn utenfor, må sies å være nødvendige observasjoner for en historisk tilnærming.

Det er dog litt vanskeligere å finne tydelige observasjoner som er tilstrekkelige. På én side kan det hevdes at en mer regional oppfatning av det sikkerhetspolitiske trusselbildet er en direkte konsekvens av truslenes natur, hvor man ser grupperinger bevege seg på tvers av grensene. Samtidig viser kildelitteraturen til at forhandlingenes sosialiseringseffekt er avgjørende for at kinesiske ledere ser på løsningen som regional. Det må på en annen side sies at å samarbeide internasjonalt om felles problemer ikke betinges av et eksisterende rammeverk, så dette kan ikke regnes som tilstrekkelige data.

Kinas avvisning av Usbekistan som medlem er dog en interessant observasjon. Det er to ting vi kan tolke ut fra denne observasjonen. Først at Kina betinger regionalt samarbeid med at man bygger videre på eksisterende rammeverk, og deretter at Kina ikke ønsker å endre dette rammeverket for å tilpasse det til nye medlemmer. Denne observasjonen er dermed tilstrekkelig for å bruke en historisk tilnærming, fordi det gir mindre rasjonell mening å begrense samarbeid med Usbekistan om regionale trusler som «de tre ondskaper» bare fordi de ikke er del av eksisterende avtaleverk.

Case IV: 2001-2006 - inn i det nye årtusenet

Nye rammevilkår

Tusenårsskiftet bringer igjen endringer i trusselbildet i Sentral-Asia. Med 11. september 2001 kommer terrorangrepene mot USA i New York og Washington D.C., og USA og NATO gjengjelder med en omfattende militær aksjon mot al-Qaida og Taliban i Afghanistan. Som et ledd i operasjonen får USA bruke baser i Kirgisistan og Usbekistan for å gjennomføre flyangrep mot mål i Afghanistan, og i etterkant av operasjonen blir store NATO-styrker værende for å stabilisere landet. For Kinas 
del betyr dette at kampen mot regionale trusler nå blir komplisert av en ny militær trussel mot grenseområdene (Zhao, 2008, s. 81). I begge saker er det klart for Kinas ledere at samarbeid med nabolandene er avgjørende. I oktober vurderer president Jiang Zemin situasjonen: «Etter den kalde krigen har det vært to endringer, den ene er fremveksten av de tre ondskaper, og den andre er USAs militære tilstedeværelse i Sentral-Asia. Bare ved å samarbeide med Russland og statene i Sentral-Asia kan vi sikre relativ stabilitet i denne strategiske retningen» (Jiang, 2001, s. 355).

Også på økonomisk side kommer et stort skifte etter tusenårsskiftet. Der man tidligere har sett en gryende handel, har både bedrifter og lokale myndigheter nå fått øynene opp for potensialet i regionalt økonomisk samarbeid. Vi ser en kraftig økning i handel etter 2001 (Zhao, 2008, s. 78). Denne handelen blir godt hjulpet av tettere samarbeid innen energi. Først rundt årtusenskiftet begynner kinesiske myndigheter med alvor å se på energipotensialet i Sentral-Asia, og man begynner å føre en mer aktiv politikk for å øke investeringene inn i nabolandene (Zhao, 2008, s. 42). Dette er særlig tydelig for Atasu-Alashankou-oljeledningen. Kina har lenge vært nølende til prosjektet, men med kraftig økning i energibehovet blir oljeimport ansett som et strategisk sikkerhetshensyn (Zhao, 2008, s. 74). Først i 2003 godkjenner president $\mathrm{Hu}$ Jintao prosjektet, og Kinas første oljeledning mot utlandet står ferdig i desember 2005 (Yuan, 2010, s. 860). Økonomiske interesser begynner derfor for alvor å skyve seg opp på Kinas agenda etter 2001.

\section{Observasjon av atferd}

2000-tallet kjennetegnes tidlig av mer formelt samarbeid på mange områder. I begynnelsen av juni 2000 står koordineringsgruppen klar med utkast til en rekke avtaler som skal undertegnes på neste toppmøte (Folkets Dagblad, 2001). I slutten av juni 2001 er Jiang Zemin vert for "Shanghai fem-gruppen», samt Usbekistan, i Shanghai. De signerer her Shanghai-konvensjonen, som slår fast at man skal stå sammen i kampen mot «de tre ondskaper», i tillegg til en erklæring som formelt oppretter Shanghai-samarbeidsorganisasjonen. Med hensyn til økonomisk vekst, fred og stabilitet oppsummerer Jiang Zemin viktigheten av regionalt samarbeid: "[V]åre strategiske interesser beror på naboland, og på at vi behandler dem bra» (He, 2012, s. 31). Erklæringen henviser samtidig til avtalene om tillitsbyggende tiltak og nedrustning som utgangspunktet for regionalt samarbeid. Likevel blir ikke disse avtalene reforhandlet for å omfatte Usbekistan, og kontrollorganet for nedrustningsavtalen forblir innenfor rammen av de fem opprinnelige medlemmene (Trofimov, 2002).

Organisasjonen fortsetter sin gradvise styrking av samarbeid innen bekjempelse av «de tre ondskaper». I 2003 avholder medlemmene sin første felles militærøvelse med fokus på kontraterror (Sheives, 2006, s. 213). Samtidig fortsetter arbeidet fra 1999 med å opprette et kontraterrororgan, som fører til at organet endelig opprettes i 2004 (Plater-Zyberk \& Monaghan, 2014, s. 20). På samme tid blir medlemmene enige om en felles erklæring hvor de ber amerikanske styrker gi en tidslinje for å trekke seg ut av basene i Sentral-Asia. På bilateralt nivå ser det likevel ut til at 
Kina etter denne erklæringen ikke presser videre på for amerikansk tilbaketrekking (Sheives, 2006, s. 221).

På andre områder er det også klare tegn til et kvalitativt skifte i organisasjonen etter årtusenskiftet. I Tadsjikistan gjenstår den siste grensetvisten med Kina, og forhandlingene står stille i 2001 (Zarifi \& Sattorov, 2014, s. 200). Jiang Zemin uttrykker bekymring for at forhandlingene står $\mathrm{i}$ veien for videre diplomatiske initiativ $\mathrm{i}$ regionen, og at en etterfølger kan undergrave den fremgangen Kina har hatt under hans styre (Bitabarova, 2015). I 2002 løses denne siste grensetvisten mellom Kina og nabolandene i Sentral-Asia ved at Kina tildeles 3,5 prosent av det opprinnelige kravet (Bitabarova, 2015). Etter at Usbekistan blir medlem, blir det samtidig diskutert om organisasjonen er åpen for ytterligere utvidelse. Dette blir tidlig avvist av Kina, som mener at det juridiske rammeverket for utvidelse ikke ligger på plass (PlaterZyberk \& Monaghan, 2014, s. 8). Først i 2004 blir Mongolia godkjent som den første observatøren siden Usbekistan, og i 2006 uttaler SCOs leder Zhang Deguang at organisasjonen ikke er lukket, men kan utvides så fort de riktige avtalene er på plass (Plater-Zyberk \& Monaghan, 2014, s. 9). Samtidig ser vi tegn til at økonomiske interesser får en større plass i organisasjonen. I 2002 signerer partene en intensjonsavtale om økonomisk samarbeid, og de oppretter en konsultasjonsmekanisme for å håndtere handelsspørsmål (Trofimov, 2002). Dette samarbeidet styrkes videre i 2006 med opprettelsen av en interbankorganisasjon (Blagov, 2005).

\section{Oppsummering}

Årtusenskiftet representerer et avgjørende skille for SCO. Forhandlingsinstitusjonen som i utgangspunktet er fokusert på grenseforhandlinger og tradisjonelle militære spørsmål, går over i en ny, multilateral organisasjon med en bred agenda.

Vi observerer få avgjørende endringer i ytre rammevilkår i denne perioden. Selv om krigen i Afghanistan er et symbol på den økende trusselen fra islamske bevegelser, foregår krigen utenfor SCOs medlemsområde. Spørsmålet om USAs tilstedeværelse i regionen er et interessant tilfelle. Selv om organisasjonen ber USA trekke seg ut på sikt, ser det ikke ut til at Kina følger dette opp videre, noe som kan antyde at de ikke ønsker å befeste SCOs stilling som noen regional allianse ut over kontraterror. Denne observasjonen virker dog ikke godt underbygget, og den kan ikke uten videre sies å være tilstrekkelig.

Innenfor både sikkerhet og økonomi ser vi i hovedsak en intensivering og ytterligere tydeliggjøring av interessene. Kimen til opprettelsen av SCO ligger nedfelt i det voksende samarbeidet mellom "Shanghai fem-gruppen", og forberedelsene til de nye avtalene ut over år 2000 og 2001, som kom på bakgrunn av en gradvis endring $\mathrm{i}$ holdninger i det kinesiske lederskapet. Interessant nok velger man her å opprette en ny organisasjon på toppen av det eksisterende rammeverket heller enn å utvide den gamle. Samarbeid innen kontraterror, utvidelse og økonomiske avtaler oppstår over flere år etter opprettelsen av SCO, som igjen bygger videre på koordinering forut for 2001. 
Opprettelsen av SCO og utformingen av den organisasjonen vi observerer i 2006, må derfor kunne kalles en rykende pistol og tilstrekkelig for å foretrekke en historisk ramme. Det reflekterer mer en gradvis utvikling av forhandlingene heller enn en reaksjon på ytre rammevilkår.

\section{Konklusjon}

Kinas holdninger til internasjonale institusjoner er et pågående spørsmål. Denne artikkelen har argumentert at skiftende ytre rammevilkår, som sikkerhetspolitiske og økonomiske interesser, ikke automatisk medfører endrede holdninger til eksisterende avtaler. Heller viser artikkelen til en serie caser over tid, hvor Kina ved flere punkter har valgt å se bort fra mulige sikkerhetspolitiske eller økonomiske gevinster ved å holde fast på eksisterende forhandlinger og gjennomføre dem heller enn å skyve dem til side.

Artikkelen har gjennomgått fire caser. De har dekket utviklingen av SCO i perioden 1986-2006 og analysert observasjoner på Kinas holdninger og handlingsmønster mot institusjonen i forhold til ytre rammevilkår. Hypotesen var at historiske hensyn, både materielle og immaterielle, har forsterket en stiavhengighet. Målet var deretter å lete etter rykende pistoler, bevis som er tilstrekkelige for å vektlegge en historisk tilnærming, heller enn å trekke linjer direkte fra sikkerhetspolitiske og økonomiske interesser til Kinas holdning. Fordi ytre rammevilkår ses på som viktige faktorer, selv i en historisk tilnærming, har analysen derfor søkt å finne viktige punkter hvor Kinas holdninger burde ha endret seg, men ikke gjorde det fordi man tok avgjørende hensyn til eksisterende avtaleverk. Analysen pekte ut disse punktene:

\section{6-1991}

- $\quad$ Kina godtok bare en utvidet sovjetisk delegasjon dersom disse anerkjente Kinas historiske krav og eksisterende avtaleverk, selv om å inkludere dem kunne ha underbygget ønsket om mer åpenhet og handel over grensen.

1991-1996

- Kina presset for å fortsette forhandlingene i samme spor heller enn å sette grensetvistene til side og fokusere på handel og stabilisering med de nye republikkene.

- Kina foretrakk å møte en felles delegasjon heller enn bilaterale forhandlinger, fordi dette åpnet for å ta utgangspunkt i eksisterende avtaleverk. Dermed svekket Kina sin økte maktposisjon.

$1996-2001$

- Kina avviser å ta opp Usbekistan som medlem av hensyn til eksisterende avtaleverk, selv om samarbeid gir mening mot felles sikkerhetstrusler. 


\section{Magnus Langset Trøan}

Den siste casen (2001-2006) stikker seg ut ved ikke å ha noen klare endringer i ytre rammevilkår som vi kan ta utgangspunkt i. Denne casen er dog nevneverdig fordi den representerer en videre krystallisering av samarbeid med bakgrunn i den historiske rammen. Opprettelsen av SCO fremtrer som en videreutvikling av beslutninger og vurderinger gjort på i 1990-årene, heller enn en reaksjon på nye interesser i 2001 . Vi får dermed inntrykk av en organisasjon som er resultatet av en stiavhengighet staket ut helt tilbake i 1980-årene.

Denne artikkelen kan ikke bevise eller avvise en rasjonell eller en historisk hypotese. Likevel viser den at i casen SCO er det tilstrekkelige observasjoner for å velge en historisk tilnærming. Forfatteren oppfordrer derfor til videre forskning for å styrke denne tilnærmingen.

\section{Om forfatteren}

Magnus Langset Trøan tok LL.M. i internasjonal politikk ved Fudan-universitetet i Shanghai i 2016, hvor han skrev om kinesiske grensetvister etter den kalde krigen. Han har siden forsket på kinesisk politikk og sikkerhetspolitikk ved Norsk utenrikspolitisk institutt (NUPI), jobbet med geopolitisk risikoanalyse og publisert flere fagfellevurderte artikler og aviskronikker på Kina-relaterte tema.

\section{Litteraturliste}

Kilder på engelsk

Ambrosio, T. (2008). Catching the «Shanghai spirit»: How the Shanghai Cooperation Organization promotes authoritarian norms in Central Asia. Europe-Asia Studies, 60(8), 1321-1344.

Axelrod, R. (1984). The evolution of cooperation. New York, NY: Basic Books.

Bailes, A. J. K. \& Dunay, P. (2007). The Shanghai Cooperation Organization as a regional security institution. SIPRI Policy Paper, (17), 1-29.

Bennett, A. (2010). Process tracing and causal inference. I H. E. Brady \& D. Collier (Red.), Rethinking social inquiry: Diverse tools, shared standards (s. 207-219). Lanham, MD: Rowman and Littlefield.

Bitabarova, A. (2015). Contested views of contested territories: How Tajik society views the Tajik-Chinese border settlement. Eurasia Border Review, 6(1), 63-81.

Blagov, S. (2005, 31. oktober). Shanghai Cooperation Organization eyes economic, security cooperation. Eurasia Daily Monitor. Hentet 21. august 2020 fra https://jamestown.org/program/shanghai-cooperationorganization-eyes-economic-security-cooperation/

Brady, H. E., Collier, D. \& Seawright, J. (2006). Toward a pluralistic vision of methodology. Political Analysis, 14(3), 353-368.

Chung, C. P. (2004). The Shanghai Co-operation Organization: China's changing influence in Central Asia. The China Quarterly, (180), 989-1009.

Chung, C. P. (2006). China and the institutionalization of the Shanghai Cooperation Organization. Problems of Post-Communism, 53(5), 3-14.

Collier, D., Mahoney, J. \& Seawright, J. (2004). Claiming too much: Warnings about selection bias. I H. E. Brady \& D. Collier (Red.), Rethinking social inquiry: Diverse tools, shared standards (s. 85-102). Lanham, MD: Rowman and Littlefield.

Cooley, A. (2012). Great games, local rules: The new great power contest in Central Asia. New York, NY: Oxford University Press.

Dadabaev, T. (2013). Shanghai Cooperation Organization (SCO) regional identity formation from the perspective of Central Asian states. Fournal of Contemporary China, 23(85), 102-118. 


\section{Effektive verktøy eller historiske rammer?}

Evans, P. B., Jacobson, H. K. \& Putnam, R. D. (Red.) (1993). Double-edged diplomacy: International bargaining and domestic politics. Berkeley, CA: University of California Press.

Fioretos, O. (2011). Historical institutionalism in international relations. International Organization, 65(2), 367-399.

Fravel, M. T. (2008). Strong borders, secure nation: Cooperation and conflict in China's territorial disputes. Princeton, NJ: Princeton University Press.

Gerring, J. (2007). Case study research: Principles and practices. Cambridge, England: Cambridge University Press.

Hall, P. A. \& Taylor, R. C. R. (1996). Political science and the three new institutionalisms. Political Studies, 44(5), 936-957.

Harding, H. (1988). China and Northeast Asia: The political dimension. New York: University Press of America.

Heilmann, S. (2008). Policy experimentation in China's economic rise. Studies in Comparative International Development, 43(1), 1-26.

Hogan, J. (2006). Remoulding the critical junctures approach. Canadian fournal of Political Science/Revue canadienne de science politique, 39(3), 657-679.

Keohane, R. O. (1984). After hegemony: Cooperation and discord in the world political economy. Princeton, NJ: Princeton University Press.

Keohane, R. O. (1988). International institutions: Two approaches. International Studies Quarterly, 32(4), 379-396.

King, G., Keohane R. O. \& Verba, S. (1994). Designing social inquiry: Scientific inference in qualitative research. Princeton, NJ: Princeton University Press.

Lanteigne, M. (2007). "In medias res»: The development of the Shanghai Co-operation Organization as a security community. Pacific Affairs, 79(4), 605-622.

Marketos, T. N. (2009). China's energy geopolitics: The Shanghai Cooperation Organization and Central Asia. London, England: Routledge.

North, D. C. (1991). Institutions. Fournal of Economic Perspectives, 5(1), 97-112.

Pan, G. (2007). A Chinese perspective on the Shanghai Cooperation Organization. SIPRI Policy Paper, (17), 45-58.

Paramonov, V. \& Stolpovskiy, O. (2009). Russia and the Central Asian countries: Bilateral security cooperation. Central Asia and the Caucasus, (2), 52-64. Hentet 24. august 2020 fra http://www.ca-c.org/online/2009/ journal_eng/cac-02/06.shtml

Pierson, P. (2000). Increasing returns, path dependence, and the study of politics. American Political Science Review, 94(2), 251-267.

Pierson, P. (2003). Big, slow-moving, and...invisible: macrosocial processes in the study of comparative politics. I J. Mahoney \& D. Rueschemeyer (Red.), Comparative historical analysis (s. 177-207). Cambridge, England: Cambridge University Press.

Plater-Zyberk, H. \& Monaghan, A. (2014). Strategic implications of the evolving Shanghai Cooperation Organization. Strategic Studies Institute. Carlisle Barracks, PA: US Army War College Press.

Putnam, R. D. (1988). Diplomacy and domestic politics: The logic of two-level games. International Organization, 42(3), 427-460.

Ro'i, Y. (1992). Nationalism in Central Asia in the context of glasnost and perestroika. I Z. Gitelman (Red.), The politics of nationality and the erosion of the USSR (s. 50-76). London: Palgrave Macmillan.

Sheives, K. (2006). China turns west: Beijing's contemporary strategy towards Central Asia. Pacific Affairs, $79(2), 205-224$.

Song H. (2016). Zhongguo waijiao juece moshi [A model for China's foreign policy-making]. Beijing: Current Affairs Press.

Song, W. (2013). Interests, power and China's difficult game in the Shanghai Cooperation Organization (SCO). fournal of Contemporary China, 23(85), 85-101.

Sutter, R. G. (2012). Chinese foreign relations: Power and policy since the Cold War (3. utg.). Lanham, MD: Rowman \& Littlefield.

Thelen, K. (2004). How institutions evolve: The political economy of skills in Germany, Britain, the United States, and fapan. Cambridge, England: Cambridge University Press.

Thelen, K. \& Steinmo, S. (1992). Historical institutionalism in comparative politics. I S. Steinmo, K. Thelen, \& F. Longstreth (Red.), Structuring politics: Historical institutionalism in comparative analysis (s. 1-32). Cambridge, England: Cambridge University Press. 


\section{Magnus Langset Trøan}

Trofimov, D. (2002). Shanghai process: From the "Five» to the cooperation organization - summing up the 1990s and looking ahead. Central Asia and the Caucasus, (2). Hentet 21. august 2020 fra https://www.ca-c. org/journal/2002/journal_eng/cac-02/11.troen.shtml

Waltz, K. N. (1979). Theory of international politics. New York, NY: McGraw-Hill.

Whiting, S. H. (2000). Power and wealth in rural China: The political economy of institutional change. Cambridge, England: Cambridge University Press.

Yuan, J.-D. (2010). China's role in establishing and building the Shanghai Cooperation Organization (SCO). fournal of Contemporary China, 19(67), 855-869.

\section{Kilder på russisk}

Amanzholova, H. A., Atanov, M. M. \& Turarbekov, B. S. (2006). Pravda o Gosudarstvennoy Granitse Respubliki Kazakhstan [Sannheten om republikken Kasakhstans landegrenser]. Almaty: Silk Road.

Ide, K. (2014). Peregovory mezhdu SSSR/Rossiej i Kitaem po uregulirovaniju pogranitsjnih voprosov [Forhandlinger mellom USSR/Russland og Kina på grensespørsmålet]. Polis, (3), 47-66.

Jablonskikh, E. B. (2011). Formirovanie i znatsjenie povestki dnja v dejatel'nosti «Šanhajskoj pjaterki» (19892001 gg.) [Utformingen og rollen av agenda under Shanghai fem-gruppen, 1989-2001]. Bulletin of the Kyrgyz-Russian Slavic University, 11(4), 120-124.

Medeubaeva, Z. M. (2012). Istorija formirovanija vnešnepolitičeskoj doktriny Respubliki Kazahstan (1991-2010 gody) [Den historiske formeringen av republikken Kasakhstans utenrikspolitiske doktrine]. Astana: L. N. Gumilyov Eurasian National University.

Savkovitsj, E. V. (2010). Pogranitsjnoe Uregulirovanie na Zapade KNR v 1990-2000-e gg. (Kazakhstan, Kyrgyzstan, Tadžikistan) [Grenseløsning i vestlige Kina i 1990-2000 (Kasakhstan, Kirgisistan og Tadsjikistan)]. Tomsk State University Bulletin, (336), 86-92.

Vereshchagin, B. N. (1999). V starom i novom Kitae: Iz vospominanij diplomata [I gamle og nye Kina: Fra en diplomats memoarer]. Moskva: Institute of Far Eastern Studies.

Zarifi, H. \& Sattorov, A. (2014). Tadžikistan-Kitaj stanovlenie gosudarstvennoj granicy. Istorïa $i$ sovremennost [Tadsjikistan-Kina: bestemming av landegrensen. Historie og modernitet]. Dushanbe: Ifron.

\section{Kilder på kinesisk}

Deng, X. (1993). Deng Xiaoping wenxuan (di san juan) [Utvalgte tekster av Deng Xiaoping (tredje bok)]. Beijing: People's Publishing House.

Di, J. (Red.) (2015). Zhongguo waijiaoguan jishi [Nedtegnelser fra kinesiske diplomater]. Beijing: World Affairs Press.

Folkets Dagblad. (1992, 4. april). E xinren zhuhua dshi Luogaoshoufu renqian shuo E-Zhong gongtong mubiao shi mulin yu hezuo [Før han tiltrer sin post, sier den nye russiske ambassadøren til Kina, Rogachev, at Kinas og Russlands felles mål er gode naborelasjoner og samarbeid].

Folkets Dagblad. (2001, 12. juni). «Shanghai wu guo» guojia xietiaoyuan di liu ci huiyi juxing [Det sjette møtet i den nasjonale koordineringsgruppen for "Shanghai Fem» avholdes].

He, Y. (2012). Zhong-Ha, Zhong-Ji, Zhong-Ta bianjie wenti yuanman jiejue de lishi guocheng ji qi qishi [Lærdommer fra den historiske prosessen med endelig å løse grensetvistene mellom Kina og Kasakhstan, Kirgisistan og Tadsjikistan]. Party History Research and Training, (1), 26.

Jiang, Z. (2001). Fiang Zemin wenxuan (di san juan) [Utvalgte tekster av Jiang Zemin (tredje bok)]. Beijing: People's Publishing House.

Li, F. (2011). Qinli Zhong-Su (E) bianjie tanpan ji [Memoarer fra de kinesisk-sovjetiske (russiske) grenseforhandlingene]. I Jiang C., Zhong-E guojie dongduan de yanbian [Utviklingen av den østlige delen av den kinesisk-russiske grensen] (s. 1-17). Beijing: Central Party Literature Press.

Liu, D. (2005). Cong tongmeng dao huoban: Zhong-E(Su) guanxi 50 nian [Fra allierte til partnere: 50 år med kinesisk-russiske/sovjetiske forhold]. Beijing: Chinese Communist Party History Publishing House.

Liu, X. (Red.) (2011). Xin Zhongguo jianjiao tanpan shilu [Forhandlingsprotokoller fra opprettelsen av diplomatiske forbindelser i det nye Kina]. Shanghai: Shanghai Lexicographical Publishing House.

Liu, D., Sun, Y. \& Liu, S. (1996). Sulian jieti hou de Zhong-E guanxi [Kinesisk-russiske relasjoner etter Sovjetunionens fall]. Harbin: Heilongjiang Education Press.

Tian, Z. (Red.) (1993). Gaige kaifang yilai de Zhongguo waijiao [Kinas utenrikspolitikk etter reform- og åpningspolitikken]. Beijing: World Affairs Press. 
Wang, J. (2001). Juyou lishi yiyi de kuayue - cong «Shanghai wu guo» dao «Shanghai hezuo zuzhi» [Et historisk sprang: Fra Shanghai fem-gruppen til Shanghai-samarbeidsorganisasjonen]. World Economics and Politics, (9), 76-81.

$\mathrm{Xu}, \mathrm{T}$. (2001). «Shanghai wu guo» jizhi de youlai ji qi yunzuo [Opprinnelsen og praktiseringen av «Shanghai fem»-mekanismen]. International Data Information, (6), 1-6.

Yao, P. (2015). Bianjie wenti suipian huiyi [Erindringer om grensetvistene]. The Contemporary World, (10), 66-69.

Zhao, H. (2008) Zhongguo de Zhongya waijiao [Kinas diplomati i Sentral-Asia]. Beijing: Current Affairs Press.

Zhang, M. \& Qi, P. (2014). Gouzhu woguo zai Zhongya diqu de guotu anquan pingzhang — Zhong-Ta bianjie tanpan yu shuangbian bianjie huading [Oppbyggingen av en sikkerhetsskjerm i Sentral-Asia: Grenseforhandlinger og bilateral grensesetting mellom Kina og Tadsjikistan]. Zhong Hua Hun, (20), 32-35.

Zhu, P. \& Duan, L. (2002). Zhonggong sandai lingdao jiti yu Xinjiang [Tredje generasjon av KKPs lederskapskollektiv og Xinjiang]. Urumqi: Xinjiang People's Press.

\section{Abstract in English \\ Efficient tools or historical frameworks? \\ China's attitude to international institutions}

In academia, it is common to assume that states participate in institutions insofar as this serves their interests at any given time. The implication is that states like China may reject international institutions as soon as they no longer consider them useful. The author argues that China lets its interests be shaped by the institutions beyond what structural factors imply. To shed light on this argument, this article conducts a case study of the development of the Shanghai Cooperation Organization (SCO) and China's attitudes to this process. Specifically, the article will draw connections from negotiations between the China and the Soviet Union over border disputes in the 1980s to the foundation of the SCO in the 2000s. By comparing a rational approach with a historical one, the article argues that the historical approach is more relevant to understand China's attitudes. It further argues that a historical approach has potential as a useful tool and should be examined further in IR.

Keywords: Central Asia $\cdot$ negotiations $\cdot$ institutionalism $\cdot$ path dependence 